\title{
CREATIVE STORY THROUGH 9GAG APPLICATION IN TEACHING SPEAKING
}

\author{
${ }^{1}$ Muhamad Sofian Hadi, ${ }^{1}$ Zaitun, \& ${ }^{3}$ Tsamara Fairuz Suni \\ ${ }^{1}$ English Lecturer, Muhammadiyah University of Jakarta, Indonesia \\ ${ }^{2}$ English Student, Muhammadiyah University of Jakarta, Indonesia \\ Corresponding Author Email: tsamara.fairuz@gmail.com
}

\begin{tabular}{|c|c|}
\hline Article Info & Abstract \\
\hline $\begin{array}{l}\text { Article History } \\
\text { Received: February } 2021 \\
\text { Revised: March } 2021 \\
\text { Published: April } 2021\end{array}$ & $\begin{array}{l}\text { This study aims to improve students' speaking abilities through creative stories } \\
\text { using the 9GAG application. The study is a quantitative method with Quasi- } \\
\text { Experimental design. Speaking tests are employed as research instruments in } \\
\text { collecting the data. The researchers used two classes of the ninth grade of MTs }\end{array}$ \\
\hline $\begin{array}{l}\text { Keywords } \\
\text { Creative Stories; } \\
\text { 9GAG application; } \\
\text { Speaking Skills; }\end{array}$ & $\begin{array}{l}\text { Al-Islamiyah, Tangerang for the population. The sampling technique used was } \\
\text { cluster sampling in which the } 9.4 \text { class was determined as the experimental class } \\
\text { and the } 9.5 \text { class as the control class. The data was analyzed statistically by } \\
\text { using a t-test to find out the significant difference. The result of this analysis } \\
\text { indicated that the average value of the students was } 70.33 \text {, the statistical } \\
\text { calculation showed that the results of to (t-observation) was greater than } t_{t}(t- \\
\text { table) in which to obtain was } 19.24 \text { while the value of } t \text {-t was } 2.015 \text { with a } \\
\text { significant level of } 5 \% \text { (0.05). Therefore, alternative hypothesis (Ha) was } \\
\text { accepted while null hypothesis was rejected. This research summarized that } \\
9 \text { GAG application has a positive effect to improve students'speaking skills. }\end{array}$ \\
\hline
\end{tabular}

How to cite: Hadi, M. S., Zaitun., \& Suni, T. F. (2021). Creative story through 9GAG application in teaching speaking, JOLLT Journal of Languages and Language Teaching, 9(2), 170-178, DOI: https://doi.org/10.33394/jollt.v\%vi\%i.3534

\section{INTRODUCTION}

Speaking skills in the English as a Foreign Language (EFL) context is interesting for students to achieve. EFL learners can be admired as successful learners if they can communicate using the foreign language effectively (Irmawati, 2016; Aprianoto \& Haerazi, 2019). Unfortunately, speaking difficulties do not only exist in low students but also happen to high achiever learners in the EFL context. Therefore, the parameter of that students have a good English skill can be observed if they are able to use English verbally in real communication. In speaking skills, some researchers have offered various solution to help students to communicate effectively. In addition, speaking problems of nonnative speakers have been studied by previous researchers (Hamad, 2012; Mazaozi, 2013; Angelini \& Garciacarbonel, 2019).

In the $21^{\text {st }}$-century era requires students and teachers to utilize technology in their learning, even in everyday life. Integrating technology into speaking classes is essential nowadays (Anugrah et al., 2019). In this era of globalization, English is important for people's lives. Globalization makes the use of English becomes more widen. There are four basics English skills that must be learned and mastered the listening, reading, speaking, and writing (Isda et al., 2021; Haryanti et al., 2021). Everyone must learn and master those four basics English skills to improve their English. Among these four, one skill that must be learned early is speaking. In Indonesia, teaching English is focused on communication skills. Speaking has an important role in the language learning process (Maryam, 2020). According to Kilcher (2010), speaking teaching-learning must be oriented in demanding students to be 
able use the target language being learnt. Therefore, the current study aims to find out the effectiveness of creative story suing 9GAG application at the senior high schools.

Speaking is the delivery of language through the mouth. In order to speak, people create sounds using many parts of their body, including the lungs, vocal tract, vocal chords, tounge, teeth and lips. Meanwhile, Khorashadyzadeh (2014: 12) states that speaking needs not only the learners understanding about the way to produce the linguistic competence such grammar, pronunciation and vocabulary but also comprehension about sociolinguistic competence such as when, why and how to speak. Meanwhile, Bahadorfar and Omidvar (2015) argue speaking skills can be categorized as good speaking skill when the listener can understand the words produced by the speaker.

Teaching English speaking skills using the three communicative activities is a learning method focusing on learner-centeredness (Haryanti et al., 2021). Students work in small groups divided by their language proficiency, i.e., high, medium, and low levels. Using this technique, students can have an opportunity to work together, providing help to others while performing the activity. The atmosphere in working in groups can lessen their fear of making mistakes when speaking English (Hasan et al., 2021). Students in the group can support others in the team needing help. They can express themselves successfully while working in groups. This can lead to self-monitoring, more confidence in speaking, and enjoyment can encourage them to participate more in learning. The results of this study supported the effectiveness of these three communicative activities in developing English speaking skills. Study development of English speaking skills using two communicative activities, Information and Roleplaying.

Speaking is one of the important skills that had to be mastered by the students in learning English. The main goal of learning English is to be able to speak English well. In fact, many students cannot speak well. They have no confidence to speak English because they are afraid to make mistakes and have no chance or much times to practice in their class because their teacher talks too much in the class (Meliala et al., 2021). Seeing this fact, the teacher should overcome this problem by applying appropriate and effective technique to teach English so that the students are interested and enjoy the learning atmosphere.

One of the techniques can be done by the teacher is by applying an interesting learning media. In order to improve students speaking skill, 9GAG media can be selected as one of the alternative choices for teachers. This media is also available as an online application which can be downloaded. This media broadcast many pictures, videos, trending news, etc. The writer will pick several pictures from this media appropriate with the students' grade. After that, the writer will ask the students to arrange the pieces of those pictures to create short story to tell in front of the class. Their performance will become their speaking practice. It is hoped that by doing this kind of strategy, students' speaking skill will be improved since 9GAG offers many interesting pictures that might attract students' interest to speak English.

Mutiarani and Saindra (2018) inform that the Music, pictures, and videos are three kinds of media usually used by language teachers to teach their students about language. Many scholars have conducted studies which applied application or video in their teaching especially in teaching speaking. In this research study, the researcher tries to apply a pleasant teaching media for speaking skill. In the context of teaching English as a foreign language in the 9th grade students of Junior High School in Indonesia, teaching speaking is aimed to teach students to be better understands on how to communicate and understand what is being said by each other. Based on the teacher, however many teachers have difficulty in teaching them to speak, difficulties come due to and confidence, lack of vocabulary knowledge, to lack of knowledge about using grammar. Thus, seeing the importance of speaking skill but many students are lack of confidence to speaking and lack of vocabulary also boring to study by book, the teachers should apply an interesting and effective media because that can be very 
influential for teaching learning and atmosphere of the class. So, the writer conducted this research to facilitate students to learn speaking skills effectively. In this study, the writer tries to apply a pleasant teaching media for speaking skill using creative story through 9GAG application.

\section{RESEARCH METHOD Research Design}

Researchers apply quantitative method using the experimental research design in this study. This method is expected to find a causal relationship in determining cause and effect (Creswell, 2012). The design of this study applied a quasi-experimental design using equivalent control group design. The students are divided into two groups, control and experimental groups. The control group is subjected to the conventional method without 9GAG application, while the experimental group is treated using creative story method with 9GAG application. The treatments were carried out in 5-6 meeting in online learning for speaking classes students. Before treatments, pre-test was carried out to see the students' speaking skills. At the end of the treatment, researchers distributed speaking tests to see the effect of creative story method using $9 \mathrm{GAG}$ application. The speaking test was designed to attain the data of this study. The instruments are distributed in both experimental and control groups. The instruments consist of some speaking questions to be answered by students. The students are asked to narrate some stories after they answered the questions orally.

\section{Population and Sample}

The population of this study was all class of the $9^{\text {th }}$-grade of MTs Al-Islamiyah Ciledug comprising five classes. Each class consists of 44-45 students. This study used two classes as samples. The B class was decided as control class and the A class becomes experimental class. The A class consists of 45 students and 44 students in the B class. In this research, researchers choose samples randomly by using cluster random sampling technique. The control class was subjected to conventional method without 9GAG application, while the experimental class was treated using creative story method with 9GAG application. The treatments are given in online learning. The schedule of speaking classes was reorganized in line with the teachers' time schedule in MTs. Al-Islamiyah.

\section{Data Analysis}

Researchers made speaking test for students in both classes. The researchers distributed the speaking test to students in the pretest before treatment and in the posttest after treatment. The control class is subjected to the conventional method while the experimental class is treated using creative story using $9 \mathrm{GAG}$ application. The total items of the speaking test include 10-15 items. The In this research, the researcher analyzed the data of speaking test results stastistically. To analyze the data, researchers used paired sample t-test. The t-test analysis aims to find out the significant difference after giving treatment. The data of this study are declared valid and reliability before moving to the t-test analysis.

\section{RESEARCH FINDINGS AND DISCUSSION Research Findings}

This study aims to investigate the effectiveness of creative stories using 9GAG application in the teaching of speaking skills at senior high schools. In this section, the researchers explain the collected data during the study conducted at MTs Al-Islamiyah Ciledug. In the first meeting, all class was given a pre-test to measure their narrative speaking skills. After the process of collecting the pre-test data, the researcher prepared the teaching materials and implemented 9GAG application to improve students speaking skill. The treatment was conducted for seven meeting. At the last meeting, the researcher gave the posttest. The result of the two tests were used as a reference for the author to analyze the students 
'improvement in speaking skills. The students' achievement in the pre-test can be presented in Table 1 as follows.

Table 1

Frequency Distribution Control Class Pre-Test

\begin{tabular}{ccc}
\hline \multirow{2}{*}{$\begin{array}{c}\text { Class } \\
\text { Interval }\end{array}$} & \multicolumn{2}{c}{ Frequency } \\
\cline { 2 - 3 } & Absolute & $\begin{array}{c}\text { Relative } \\
\%\end{array}$ \\
\hline 40 & 22 & $48.89 \%$ \\
\hline 45 & 12 & $26.67 \%$ \\
\hline 50 & 5 & $11.11 \%$ \\
\hline 60 & 2 & $4.44 \%$ \\
\hline 65 & 1 & $2.22 \%$ \\
\hline 70 & 2 & $4.44 \%$ \\
\hline 75 & 1 & $2.22 \%$ \\
\hline TOTAL & 45 & $100 \%$ \\
\hline & &
\end{tabular}

Before giving treatment, students are provided speaking tests to see their speaking skills. In facts, students still have difficulties to address their ideas orally. Students also have lack vocabulary and lack of pronunciation knowledge. They pronoun some words wrongly. Based on the results of speaking tests, Table 1 shows that the students' speaking skills are below standards from passing grade enacted by the senior high schools. The students' score can be figured in Figure 1 as follows.

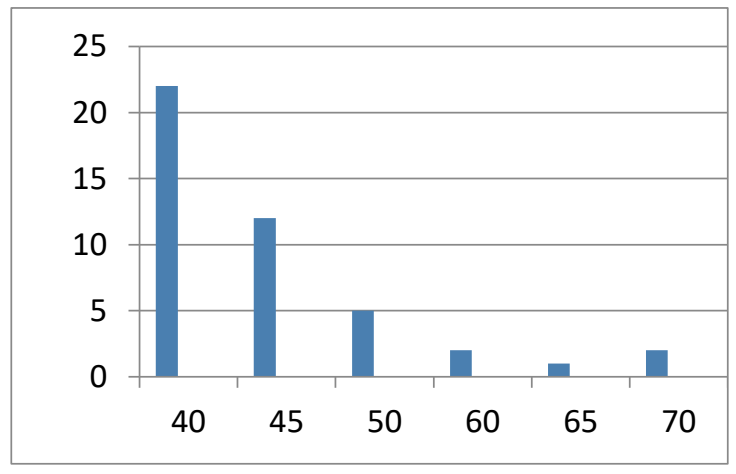

Figure 1. Diagram of Frequency Distribution of Pre-Test Control Class

Table 2

Frequency Distribution Experimental Class Pre-Test

\begin{tabular}{ccc}
\hline \multirow{2}{*}{$\begin{array}{c}\text { Class } \\
\text { Interval }\end{array}$} & \multicolumn{2}{c}{ Frequency } \\
\cline { 2 - 3 } & Absolute & Relative \% \\
\hline 40 & 22 & $48.89 \%$ \\
\hline 45 & 17 & $37.78 \%$ \\
\hline 55 & 2 & $4.44 \%$ \\
\hline 65 & 1 & $2.22 \%$ \\
\hline 75 & 3 & $6.67 \%$ \\
\hline TOTAL & 45 & $100 \%$ \\
\hline
\end{tabular}

The same achievement of speaking skills as control class are demonstrated in Experimental class. students still have difficulties to address their ideas orally. Students also have lack vocabulary and lack of pronunciation knowledge. They speak in ungrammatical 
structures. Also, they pronoun some words wrongly. Based on the results of speaking tests, Table 2 shows that the students' speaking skills are below standards from passing grade enacted by the senior high schools. The students' speaking skills in experimental class can be shown in Figure 2 as follows.

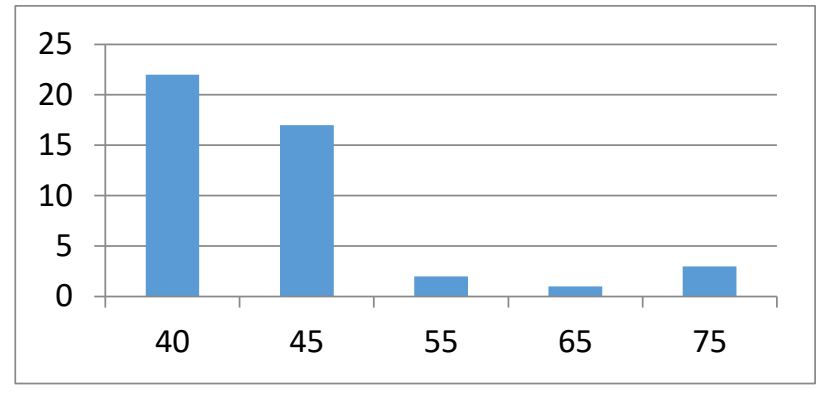

Figure 2. Diagram of Frequency Distribution of Pre-Test Experimental Class

The students' speaking achievement in the post-test of control class seems no improvement. Mostly, students got speaking achievement below standard from passing grades enacted by the school. It means the use of conventional learning technique or method has no effect toward students' speaking skills. The scores of speaking skills in control class can be seen in Table 3 as follows.

Table 3

Frequency Distribution Control Class Post-Test

\begin{tabular}{ccc}
\hline \multirow{2}{*}{$\begin{array}{c}\text { Class } \\
\text { Interval }\end{array}$} & \multicolumn{2}{c}{ Frequency } \\
\cline { 2 - 3 } & Absolute & Relative \% \\
\hline 65 & 17 & $37.78 \%$ \\
\hline 70 & 14 & $31.11 \%$ \\
\hline 75 & 10 & $22.22 \%$ \\
\hline 80 & 4 & $8.89 \%$ \\
\hline TOTAL & 45 & $100 \%$ \\
\hline
\end{tabular}

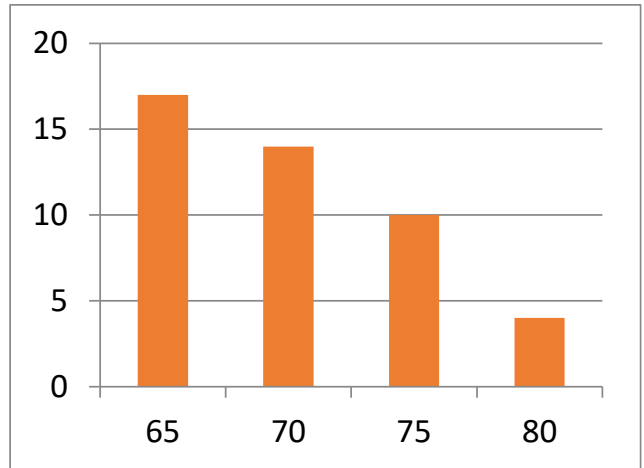

Figure 3. Diagram of Frequency Distribution of Post-Test Control Class

The students' speaking skills have been improved after they are treated using creative story with applying 9GAG application. Students can practice to speak and correct their pronunciation using 9GAG application. Although some students still feel difficult to improve their pronunciation, students motivate to develop their speaking skills through practice and practice to communicate using stories provided by teachers. The students' mean scores in the experimental class are increased and it achieves the passing grade. It can be seen in Table 4. 
Table 4

Frequency Distribution Experimental Class Post-Test

\begin{tabular}{ccc}
\hline \multirow{2}{*}{$\begin{array}{c}\text { Class } \\
\text { Interval }\end{array}$} & \multicolumn{2}{c}{ Frequency } \\
\cline { 2 - 3 } & Absolute & Relative \% \\
\hline 65 & 15 & $33.33 \%$ \\
\hline 70 & 18 & $40.00 \%$ \\
\hline 75 & 8 & $17.78 \%$ \\
\hline 80 & 2 & $4.44 \%$ \\
\hline 85 & 2 & $4.44 \%$ \\
\hline TOTAL & 45 & $100 \%$ \\
\hline
\end{tabular}

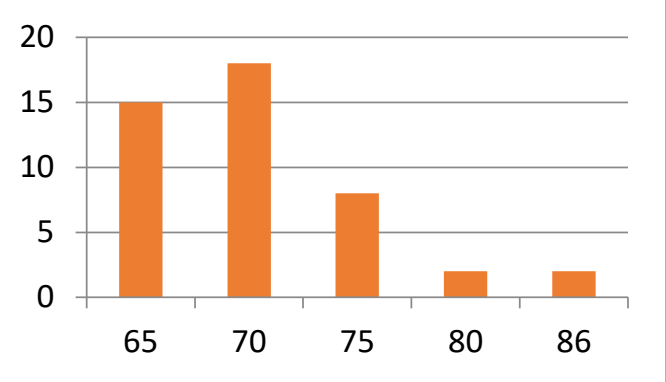

Figure 4. Diagram of Frequency Distribution of Pre-Test Experimental Class

Based on the result of pre-test and post-test of the students above, the writer analyzed the results to find out the influence of 9GAG application in teaching speaking. Based on the calculation above the result of control class is $20.606>2.015$ and for experimental class is $19.294>2.015$. The result of the data analysis showed that by using the t-test formula the result of $t_{\text {cal }}$ are 20.606 and 19.294 higher than $t_{\text {table }}$ 2.015. In conclusion, applying 9GAG application in teaching speaking skill was effective.

\section{Discussion}

This study is aimed at finding out the effectiveness of creative stories using 9GAG application to improve students' speaking skills at senior high schools. In this study, teachers guide students to prepare creative ways to focus on their lesson provided. The topics are creative stories taken from 9GAG application. The use of 9GAG application in this study aims to attract students' motivation and interest to speak by using stories taken from this media. It is in line with Listiyaningsih et al. (2020) who inform the use of 9GAG application containing humorous, fearing, annoying, pitiful, and confusing memes can facilitate students to improve their language skills such as speaking and reading activities.

In the learning processes, teachers feel easy to arrange their speaking activities to be read by students. Reading aloud activities are oriented to train students to pronoun any English words. Students are asked to manage their speaking activities by paying attention to set classroom atmosphere. This finding is proven by Jatiyasa (2019) who confirms that utilizing humour in EFL classes is effective to manage an effecting learning setting and it also creates smooth atmosphere between teachers and students. The same finding is presented by Tunnisa et al. (2019) in which they found that the use of humour illustrated in various stories is essential for students to encourage them to communicate. In the current study, students are asked to practice speaking with teachers and students-students. The speaking topics are based on stories taken from 9GAG application.

The implementation of creative stories encourages students to understand the topic which is going to present. The simple stories are discussed in small groups. Afterwards, teachers create the stories using 9GAG. The form of stories is designed in various forms such 
as memes, humours, and simple texts. In pairs, students practice to read and present it in front of students. Since students practice speaking, teachers analyze the students' pronunciation, sentence structures, accuracy, word choice, and ideas. At the end, students are provided feedback orally. During learning processes, students look motivated to revise their pronunciation, sentence structures, and accuracy. Therefore, the use of creative stories with applying 9GAG application improve and develop students' speaking performance. It is in accordance with Pranoto and Suprayogi (2020) who inform incorporating 9GAG such as games, texts, and humours is able to facilitate students to develop their speaking performance and encourage students to have willingness to communicate in the learning activities.

Based on the result of t-test above, 19.24 was obtained in the degree of freedom (df) of $44(45-1=44)$. In the degree of significance level of $5 \% 2.015$ was gained. If it is compared to each score in the degree of significance then the result were19.24 $>2.015$. Since $t_{o}$ was higher than $t_{t}$ score obtained from the result of the calculation, the positive hypothesis $\left(\mathrm{H}_{1}\right)$ can be accepted while the negative hypothesis $\left(\mathrm{H}_{0}\right)$ was rejected. Thus, it can be concluded that 9GAGapplication is effective in improving students' speaking skill of the eleventh grade students of MTs Al-Islamiyah Ciledug in academic year of 2020-2021.

\section{CONCLUSION}

After presenting and analyzing data in the previous chapter, the writer concluded that 9GAG application can improve students' speaking skill. It can be seen from the students' improvement between pre-test and post-test. From the result, the writer concluded that 9GAG application can improves speaking skills in learning process. The result shows that the average of pre-test was 45.44 and post-test was 70.33. The value of $\mathrm{T}_{\text {calculation }}$ (19.294) was higher than the value of $\mathrm{T}_{\text {table }}(2.015)$ at the significance level of $5 \%$ it can be concluded that null hypothesis $\left(\mathrm{H}_{0}\right)$ was rejected and alternative hypothesis $\left(\mathrm{H}_{1}\right)$ was accepted. It means that there is significant different between teaching speaking skill without 9GAG application. Therefore, it can be concluded that 9GAG application improves students' speaking skill. It gives a significant effect of students' speaking skill of ninth grade students in MTs AlIslamiyah Ciledug.

\section{ACKNOWLEDGEMENTS}

Researchers would like to express my thankful to my God Allah SWT who always give happiness to them in everything researchers do. Second, researchers would like to express the warm gratitude for all friends and teachers who contribute comments and suggestions in this study so this study can be accomplished in the exact time.

\section{REFERENCES}

Agustina, L., \& Setiawan, R. (2020). Fostering a natural atmosphere; improving students' communication skill in a business meeting. Journal of Languages and Language Teaching, 8(3), 307-314. doi: https://doi.org/10.33394/jollt.v8i3.2746

Aprianoto, \& Haerazi. (2019). Development and assessment of an interculture-based instrument model in the teaching of speaking skills. Universal Journal of Educational Research, 7(12), 2796-2805. https://doi.org/10.13189/ujer.2019.071230

Angelini, M. L., \& García-Carbonell, A. (2019). Developing English speaking skills through simulation-based instruction. Teaching English with Technology, 19(2), 3-20.

Anugrah, N. J., Sumardi, S., \& Supriyadi, S. (2019). Integrating "Daily Learn English Application" to Teach Speaking Skill in EFL Classroom. Indonesian Journal of EFL and Linguistics, 4(2), 181. https://doi.org/10.21462/ijefl.v4i2.163 
Arends, R. and Kilcher, A. (2010). Teaching for student learning: becoming an accomplished teacher.

Bahadorfar, M. \& Omidvar, R. (2015). Technology in teaching speaking skill. Acme International Journal of Multidisciplinary Research, 2(4), 9-13. Retrieved from http://ejournal.radenintan.ac.id/index.php/ENGEDU/article/view/879

Creswell, J. W. (2012). Educational Research: Planning, Conducting, and Evaluating Quantitative and Qualitative Research (4th ed.). Boston: Pearson. Retrieved from https://www.pearson.com/us/higher-education/product/Creswell-Educational-ResearchPlanning-Conducting-and-Evaluating-Quantitative-and-Qualitative-Research-4thEdition/9780131367395.html

Hamad, M. (2012). Factors Negatively Affect Speaking Skills at Saudi Colleges for Girls in the South. English Language Teaching, English Language Teaching, 6(12), 87-97.

Haryanti, D., Indah, R., \& Wahyuni, S. (2021). Enhancing oral proficiency using three steps interview technique for eleventh graders. Journal of Languages and Language Teaching, 9(1), 61-68. doi: https://doi.org/10.33394/jollt.v9i1.3271

Hasan, M., Islam, A., \& Shuchi, I. (2021). Using mobile-based formative assessment in ESL/EFL speaking. Journal of Languages and Language Teaching, 9(1), 117-125. doi:https://doi.org/10.33394/jollt.v9i1.3449

Irmawati, D. K. (2016). What Makes High-Achiever Students Hard to Improve Their Speaking Skill? Journal of English Educators Society, 1(2), 71. https://doi.org/10.21070/jees.v1i2.442

Isda, I., Purwati, P., \& Imran, I. (2021). The effect of using blended learning model on enhancing students' speaking skill in senior high schools. Journal of Languages and Language Teaching, 9(1), 92-98. doi: https://doi.org/10.33394/jollt.v9i1.2921

Izzah, L \& Hadi, M. . (2019). Engaging Learners with theInternet of Things (loT): GenZ's Perspectives. Educational Initiatives Research Colloquium. Retrieved from https://www.researchgate.net/profile/Mohd-Asnorhisham-Adam/publication.pdf

Jatiyasa, I, W. (2019). Implementasi humor dalam pembelajaran di STKIP agama Hindu Amlapura. Jurnal Mitra Pendidikan, 3(1), 65-80.

Khorashadyzadeh, A. (2014). Why to use short stories in speaking classes? International Journal of Foreign Language Teaching in the Islamic World, 2(1), 9-15. Retrieved from https://www.semanticscholar.org/paper/IJLT-Why-To-Use-Short-Stories-inSpeaking-Classes-Khorashadyzadeh/ff11c97ca343c43e0fa4102e5bfc7065828984fe

Kalantari, F. \& Hashemian, M. (2015). A story-telling approach to teaching English to young EFL Iranian learners. Journal of English Language Teaching, 9(1), 221-234. https://doi.org/https://files.eric.ed.gov/fulltext/EJ1087083.pdf

Listiyaningsih, F., Rukmini, D., \& Sutopo, D. (2020). Digital literacy via readers' responses towards humor presented in "9GAG memes." English Education Journal, 10(2), 214224

Ma, Q., and Sin, C. H. (2015). Teaching young learners English vocabulary with readingbased exercises in a real classroom situation. Porta Linguarum, 23, 125-138. https://doi.org/http://www.ugr.es/ portalin/articulos/PL_numero23/8\%20\%20MA\%20Q ing.pdf

Maryam, S. (2020). Utilizing communicative language games to improve students' speaking ability. Journal of Languages and Language Teaching, 8(3), 251-263. doi: https://doi.org/10.33394/jollt.v8i3.2733

Mazaozi, S. (2013). Analysis of Some Factors Affecting Learner's Oral Performance University of Mohamed http://www.paaljapan.org/resources/proceedings/PAAL10/pdfs/hyesok.pdf 
Meliala, E., Purba, P., Panjaitan, L., Doloksaribu, L., \& Tarigan, N. (2021). An analysis of English teachers' creativity in media-based learning at the tenth-grade students. Journal of Languages and Language Teaching, 9(1), 105-110. doi: https://doi.org/10.33394/jollt.v9i1.3388

Mutiarani and Saindra, R. M. (2018). Using Graphic Organizer to Improve Students' Speaking Skills. English Language in Focus (ELIF), 1-10. https://doi.org/https://jurnal.umj.ac.id/index.php/ELIF/article/download/4499/3192.

Pranoto, B. E., \& Suprayogi, S. (2020). Incorporating 9GAG memes to develop EFL learners' speaking ability and willingness to communicate. IJEE Indonesian Journal of English Education, 7(2), 130-144. https://doi.org/https://doi.org/10.15408/ijee.v7i2.17496

Tunnisa, D., Mahmud, M., \& Salija, K. (2019). Investigating teacher's sense of humor in Indonesia. International Journal of Language Education, 3(2), 99-114. https://doi.org/10.26858/ijole.v3i2.10201

Wisnumurti, P., Setyaningsih, E., \& Wahyuni, D. (2021). Digital storytelling in TEYL: a narrative inquiry of a pre-service teacher. Journal of Languages and Language Teaching, 9(1), 1-13. doi: https://doi.org/10.33394/jollt.v9i1.3338 